\title{
Republic of Poland: Technical Note on Impaired Loans
}

This Technical Note on Impaired Loans was prepared by a staff team of the International Monetary Fund as background documentation for the periodic consultation with the member country. It is based on the information available at the time it was completed in July 2013. The views expressed in this document are those of the staff team and do not necessarily reflect the views of the government of the Republic of Poland or the Executive Board of the IMF.

The policy of publication of staff reports and other documents by the IMF allows for the deletion of market-sensitive information.

Copies of this report are available to the public from

International Monetary Fund $\bullet$ Publication Services

700 19th Street, N.W. • Washington, D.C. 20431

Telephone: (202) $6237430 \bullet$ Telefax: (202) 6237201

E-mail: publications@imf.org • Internet: http://www.imf.org

International Monetary Fund

Washington, D.C. 


\title{
FinANCIAL SECTOR ASSESSMENT PROGRAM UPDATE REPUBLIC OF POLAND
}

\author{
IMPAIRED LOANS \\ TECHNICAL NOTE
}

JULY 2013

INTERNATIONAL MONETARY FUND

MONETARY AND CAPITAL MARKETS DEPARTMENT
THE WORLD BANK FINANCIAL SECTOR VICE PRESIDENCY EUROPE AND CENTRAL ASIA REGION 


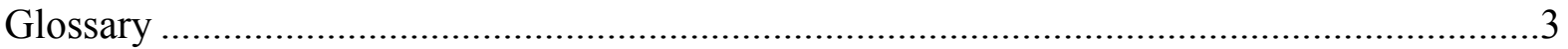

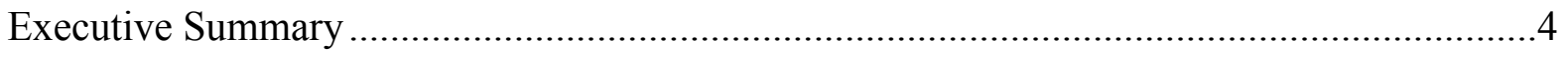

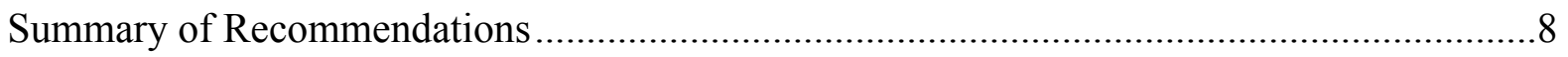

I. Overview of Impaired Loan Portfolio ................................................................

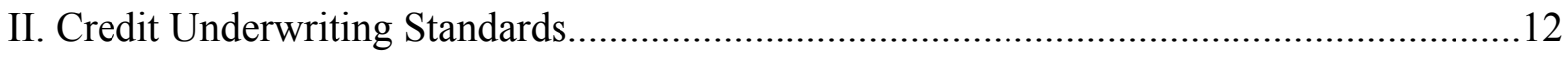

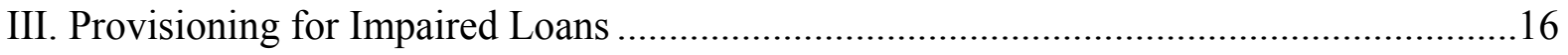

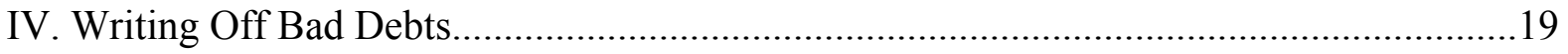

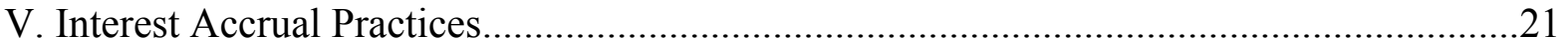

VI. Approaches Taken to Address Bad Debts .......................................................................22

A. Restructuring Loans - Retail and Corporate......................................................22

B. Restructured Loans-Regulatory Aspects ......................................................23

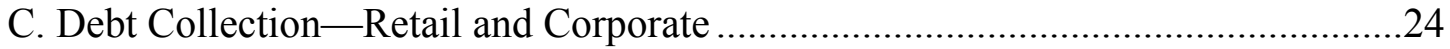

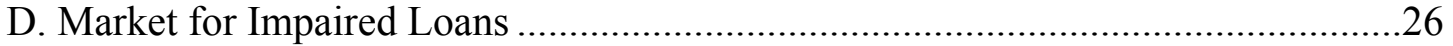

Tables

1. Comparison of Selected Features of Regulatory Recommendations for Mortgage and

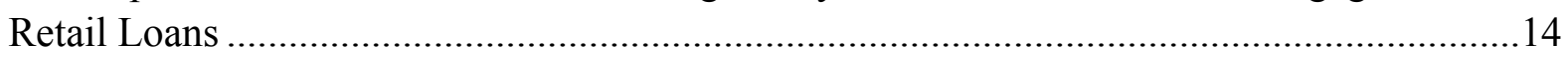

2. Provisioning for Accounting and Tax Purposes ..........................................................17

Figures

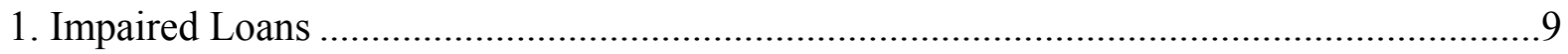

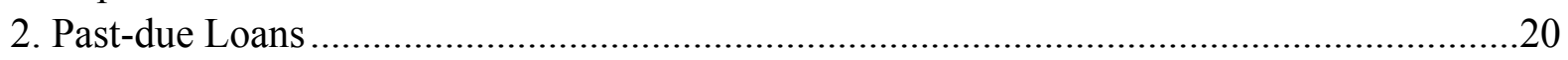

Boxes

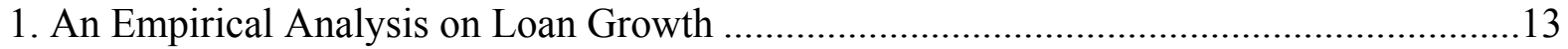

2. Summary of Polish Bankruptcy Law .......................................................................27 


\section{GLOSSARY}

$\begin{array}{ll}\text { ARM } & \text { Adjustable-Rate Mortgage } \\ \text { BCBS } & \text { Basel Committee on Banking Supervision } \\ \text { BIK } & \text { Biuro Informacji Kredytowej S.A. (Credit Information Bureau) } \\ \text { DTA } & \text { Deferred Tax Asset } \\ \text { DTI } & \text { Debt-to-income } \\ \text { FSI } & \text { Financial Soundness Indicators } \\ \text { FX } & \text { Foreign Exchange } \\ \text { GAAP } & \text { Generally Accepted Accounting Principles } \\ \text { IFRS } & \text { International Financial Reporting Standards } \\ \text { KNF } & \text { Polish Financial Supervision Commission } \\ \text { LGD } & \text { Loss Given Default } \\ \text { LTV } & \text { Loan-to-Value } \\ \text { PAS } & \text { Polish Accounting Standards } \\ \text { PD } & \text { Probability of Default } \\ \text { SME } & \text { Small and Medium Enterprise }\end{array}$


Asset quality has moved up the Polish supervisor's agenda to address persistent impaired loans and cyclical deterioration in credit quality. While the deterioration has been mainly observed in the quality of consumer loan portfolio, the foreign exchange (FX) mortgage loan portfolio also presents vulnerabilities which lie in exposure to foreign exchange risk. $A$ thematic supervisory review of impaired loans is under way, which should lead to updated regulatory guidance. Tax disincentives, interest income accrual practices, underdeveloped securitization markets, and impediments in out-of-court restructurings impede rapid progress in cleaning up bank balance sheets. The market for distressed debt is growing. A recent loosening of underwriting standards for retail loans could contribute to rising inflows into impaired loans. However, opportunities exist for the authorities to strengthen underwriting standards for mortgages to ensure flows into this asset class remain of high quality.

\section{EXECUTIVE SUMMARY ${ }^{1}$}

Asset quality deteriorated rapidly between 2008 and 2009. The increase in impaired loans $^{2}$ is most notable in the consumer loan portfolios, due to very lenient underwriting practices observed before 2008. The corporate sector's capacity to repay bank credit was affected by the 2008-09 financial crisis and the economic slowdown in 2009, resulting in a doubling of its impaired loan ratio between end 2008 and end- 2010. The overall impaired loan ratio stabilized at above 8 percent after 2010, reflecting tightening of underwriting standards, credit expansion and sales of impaired consumer loans. Overall the reserve coverage for impaired loans is 54 percent; however, coverage ranges between 36 and 77 reflecting lower coverage for certain sectors, such as the SME sector.

With the economic slowdown and expected rise in unemployment, asset quality is likely to deteriorate further. Financial difficulties in a few large construction companies that implemented public infrastructure projects (i.e., roads and motorways) impacted the corporate asset class in 2012 and as such, impaired loans increased by 35 percent - the highest increase for all asset classes. Recent revisions to Recommendation $\mathrm{T}$ carry risks as the fixed norms regarding the maximum debt-to-income (DTIs) are no longer required. ${ }^{3}$ The mortgage portfolio has so far been spared the negative effects of the global financial crisis, yet the portfolio is still young - 60 percent of the mortgage portfolio has a maturity of

\footnotetext{
${ }^{1}$ This Technical Note was prepared by Nancy Rawlings (MCM) and Yinqiu Lu (EUR). The authors are grateful for comments received from their departments and LEG.

${ }^{2}$ The definition of "impaired loans" is included in Recommendation R, which sets forth guidance for impaired loans and provisioning and is directed towards banks that follow International Financial Reporting Standards (IFRS) and is also included in regulatory reporting guidelines. For IFRS banks, the definition is similar to the one contained in the IFRS accounting rules. For banks following Polish Accounting Standards (PAS), the definition of impaired loans is "past due loan."

${ }^{3}$ Recommendation $\mathrm{T}$ sets forth the supervisory guidance for retail lending.
} 
10 years or more - and risks and inefficiencies exist, in particular sensitivity to FX volatility, funding risk, and the lack of long-term funding sources. Proposed changes to Recommendation S will also carry similar risks as Recommendation T as DTI thresholds will also be lifted; however, proposals to Recommendation S would tighten loan-to-value (LTV) and income requirements for FX mortgages, both of which will strengthen the sector. ${ }^{4}$

\section{Disincentives and social and legal obstacles impede rapid progress in cleansing of bank balance sheets. The majority of loans past due 90 days or more have been past due at least one year and the consumer loan asset class comprises almost half of this stock. The housing stock and corporate stock comprises roughly 20 percent each. While this "overhang" of impaired loans is covered to a large extent by provisions, maintaining them on the balance sheet weighs on the resolution process and distorts financial indicators. A high level of impaired loans could also potentially weigh on credit expansion (Box 1). Banks are legally allowed to accrue high rates of interest on impaired loans for three years after which the debtor stops repaying which may provide disincentives for speedy resolution. ${ }^{5}$ Further, the current tax law is restrictive on the amount of provisions or losses that are tax deductible, creating incentives for banks to underprovision. ${ }^{6}$ Moreover, limited creditor protection rights makes out of court restructurings for corporate loans unattractive, although this is changing. Finally, mortgage foreclosures and evictions carry social costs and legal challenges.}

\section{With impaired loans likely to increase and restructuring becoming more pressing, the need to address the obstacles in reducing the current impaired stock quickly has become more pressing. The key mitigating actions that should be undertaken are as follows:}

- $\quad$ Tightening oversight over credit risk management practices: The newly amended Recommendation $\mathrm{T}$ and certain of the proposed changes to Recommendation $\mathrm{S}$ will loosen the fixed norms regarding the maximum limits for DTIs for banks and place greater responsibility on bank Boards for oversight of risk management. ${ }^{7}$ Many

\footnotetext{
${ }^{4}$ Recommendation S sets forth the supervisory guidance for mortgage lending.

${ }^{5}$ The MOF establishes the "statutory limitation interest rate" or penalty rate for nonpaying loans. It is periodically adjusted and in 2012, the rate is 13 percent. However, in practice banks impose higher interest rates on past due loans.

${ }^{6}$ Provisions for doubtful loans are tax deductible up to the amount of 25 percent (50 percent in case of legally restructured corporate loans). Provisions up to 100 percent of the loan value can be recognized for uncollectible loans, but only if their loss is legally confirmed by the court or proven probable according to the tax law; for example, by death, legal insolvency, liquidation, or restructuring of the debtor.

${ }^{7}$ Previously, Recommendation T established a maximum ratio of DTI at 50 percent to 65 percent. Under the proposed changes to Recommendation S, while DTI thresholds will be lifted, banks will be required to pay special attention to loans that would bring the DTI for a given client above 40 percent to 50 percent (depending on income).
} 
countries have not established regulatory DTI limits and banks are allowed to determine their own thresholds given their credit risk tolerances, however, as a consequence, supervisory oversight of banks' credit risk management policies and practices by the supervisor becomes more complex as the supervisory responsibility shifts from a compliance focus (i.e., verifying that DTI thresholds are not exceeded) to more of a risk management focus (i.e., understanding how the bank's Board is managing risk and that its oversight of the bank's risk management practices is effective). The Polish Financial Supervision Commission (KNF) will need to ensure that banks' credit lending policies and practices remain appropriate and substantially better than pre-2008 practices. This can be accomplished during their on-site visits and perhaps through surveys. Mechanisms to promote nonbank financial institutions' reporting to the credit bureau would assist banks in their underwriting decisions given the increase in lending by these institutions.

- Increasing vigilance over restructuring practices: Supervisors should tighten the definition of restructured loans and collect more granular data on restructured loans on a monthly basis. Banks may have different definitions of "restructured" loans and are only reporting the total amount of restructured loans, sector composition, and amount of impaired restructured loans and related provisions. Information should be collected on performance, re-aging, amount modified year to date, and accruals and cash revenues. Banks should also be required to disclose their restructuring activities in their Basel II Pillar III reports.

- $\quad$ Strengthening accounting practices: While most banks' models for calculating incurred losses are sophisticated and follow international accounting standards, there is room for aggressive accounting treatment and thus there may be a risk that levels of provisions are too low or too high given the flexibility in determining the model assumptions, including the discount rates, probability of defaults (PDs), loss given defaults (LGDs), cure rates, and recovery rates. The practice of continuing to accrue income on impaired loans should also be reviewed. KNF intends to conduct thematic reviews of impaired loan portfolios for 13 banks in 2013. Conclusions drawn from these reviews should be communicated to the industry and guide modifications to Recommendation $\mathrm{R}$ or provide a useful basis for additional guidance. ${ }^{8}$ Guidance should include an interest nonaccrual principle and a standardization of risk inputs.

- Improving the insolvency framework to preserve value and lower collection costs (Box 2). Poland still has a liquidation culture when it comes to insolvency though it is incrementally moving towards a system that encompasses rescue or rehabilitation. Creditors lack an effective voice in the insolvency process. There is no effective

\footnotetext{
${ }^{8}$ Recommendation R sets forth guidance for impaired loans and provisions.
} 
supervisory mechanism over insolvency cases. On out-of-court restructuring, creditors' rights can be enhanced by adopting an out-of-court code of conduct to increase the effectiveness and efficiencies. The market for impaired mortgage loans is still incipient, and one way to increase efficiency is to ease the transfer of security right in case of assignment of impaired loans from loan originators to the buyers of impaired loans. 


\section{SUMMARY OF RECOMMENDATIONS}

\begin{tabular}{|c|c|c|}
\hline Recommendation & $\begin{array}{l}\text { Responsible } \\
\text { Party }\end{array}$ & $\begin{array}{l}\text { Time } \\
\text { Frame }\end{array}$ \\
\hline $\begin{array}{l}\text { Objective: Strengthen accounting practices for impaired loans } \\
\text { Revise Recommendation R based on thematic reviews or introduce } \\
\text { separate guidance that addresses standardization of risk inputs for loss } \\
\text { provisioning models and nonaccrual of interest income on impaired loans. }\end{array}$ & KNF & Med \\
\hline Objective: Intensify credit risk management practices & & \\
\hline $\begin{array}{l}\text { Ensure credit underwriting standards do not reflect pre-2008 practices; } \\
\text { Define DTI more precisely so a standard calculation exists for banks to } \\
\text { follow and for supervisors to assess; }\end{array}$ & KNF & $\begin{array}{l}\text { Short } \\
\text { Short }\end{array}$ \\
\hline $\begin{array}{l}\text { Tighten definition of restructured loan and collect more data on } \\
\text { restructuring activities of banks; } \\
\text { Consider conducting thematic reviews of restructured loans. }\end{array}$ & $\begin{array}{l}\text { KNF } \\
\text { KNF }\end{array}$ & $\begin{array}{l}\text { Short } \\
\text { Med }\end{array}$ \\
\hline Objective: Increase transparency & & \\
\hline $\begin{array}{l}\text { Require banks to disclose their restructuring activities in Basel II Pillar III } \\
\text { reports; }\end{array}$ & KNF & Short \\
\hline $\begin{array}{l}\text { Require banks to disclose more thoroughly their provisioning practices in } \\
\text { Basel II Pillar III reports. }\end{array}$ & KNF & Short \\
\hline $\begin{array}{l}\text { Objective: Remove tax and legal obstacles for managing impaired } \\
\text { loans }\end{array}$ & & \\
\hline Consider enhancing tax deductibility of loan loss provisions; & MOF & Short \\
\hline $\begin{array}{l}\text { Ease insolvency procedures, and develop a secondary market for selling } \\
\text { impaired mortgage loans; }\end{array}$ & $\begin{array}{l}\text { MOF, MOJ, } \\
\text { KNF }\end{array}$ & Med \\
\hline $\begin{array}{l}\text { Enhance creditor's protection rights by adopting out-of-court code of } \\
\text { conduct. }\end{array}$ & MOJ & Med \\
\hline $\begin{array}{l}\text { Objective: Promote importance of recognizing losses on banks' } \\
\text { balance sheets in timely manner } \\
\text { The KNF and the Poland Banking Association should be more aggressive } \\
\text { and consult the tax authorities and push for changes in the law. }\end{array}$ & $\begin{array}{l}\text { KNF and } \\
\text { Polish } \\
\text { Banking } \\
\text { Association }\end{array}$ & Med \\
\hline
\end{tabular}




\section{OVERVIEW OF IMPAIRED LOAN PORTFOLIO}

\section{As of December 31, 2012, impaired loans represented 8.8 percent of the total} loan portfolio compared to approximately 4.4 percent prior to the 2008 crisis. ${ }^{9}$ The distribution ranges from 1.8 percent for the FX mortgage portfolio to 17 percent for the consumer loan portfolio. Impaired consumer and small and medium enterprise (SME) loans each comprise about 30 percent of the total impaired loan portfolio and impaired housing and large corporate loans each comprise about 15 percent of the total impaired portfolio with other loans comprising slightly above 10 percent. A significant portion of the impaired loan portfolio (45 percent) is over 180 days past due (Figure 1).

Figure 1. Poland: Impaired Loans

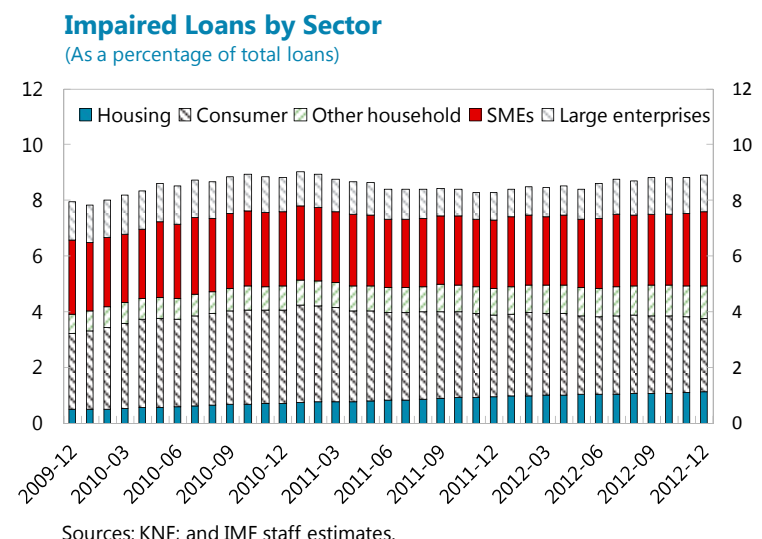

Impaired Loans by Sector

(As of end-2012)

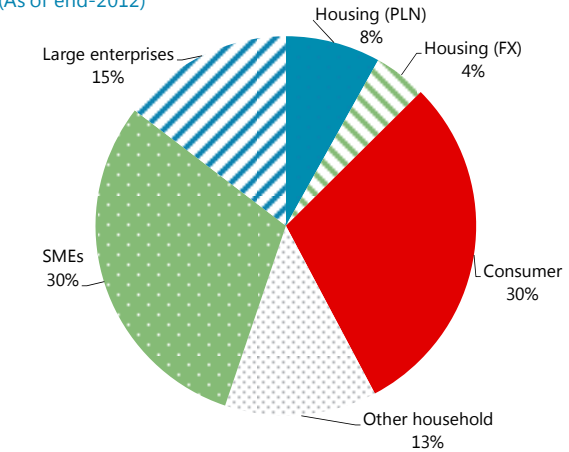

Sources: KNF; and IMF staff estimates.

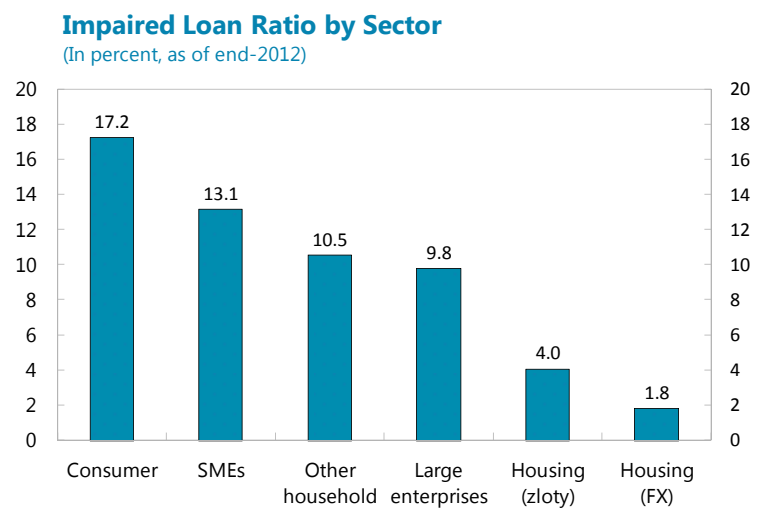

Sources: KNF; and IMF staff estimates.

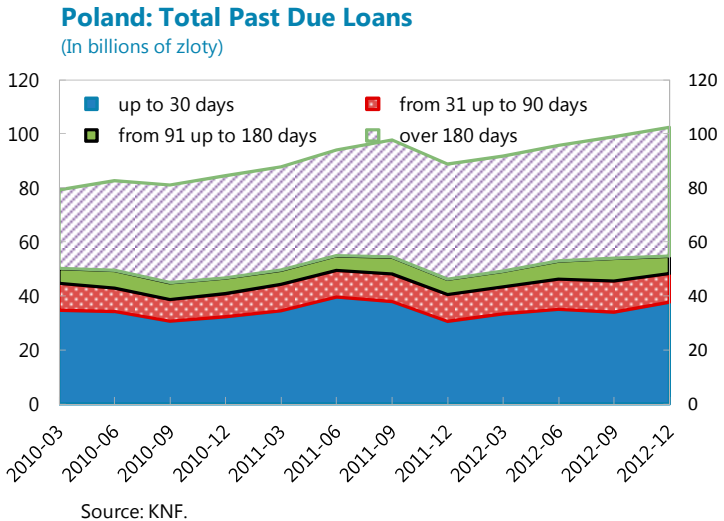

\footnotetext{
${ }^{9}$ The loan portfolio discussed in this note comprises nonfinancial sector loans - households and nonfinancial corporations.
} 
2. The impaired loan ratio spiked after the crisis in $\mathbf{2 0 0 9}$ and has stabilized over eight percent since then, mainly due to lenient underwriting standards prior to 2008 and fast credit growth in 2010 and 2011. ${ }^{10}$ The growth in impaired loans, however, has been uneven in the various nonfinancial sectors. The increase in impaired loans between 2009 and 2012 is most notable in the consumer and housing portfolios where the nonperforming ratio has increased by 4 percentage points and 1.25 percentage points, respectively since December 2009. The increase in the nonperforming ratio for consumer loans would have been higher but the portfolio shrank during the last few months of 2012 due to a couple of sizeable portfolio sales by banks (and thereby decreasing the distortion of FSIs somewhat). The nonperforming ratio of large enterprise corporate loans has been volatile but remains below 10 percent while the SME impaired loan portfolio has decreased slightly from 2009 from 13.3 percent to 13.1 percent. While credit growth has increased for the housing and SME sectors, the level of large corporate lending has actually decreased by 3.0 percent since 2009 due to a declining economy and troubles in the construction industry.

\section{FX mortgages increased rapidly through 2008 but their production has since} abated. FX mortgages comprise about 22 percent of the total loan portfolio and more than half of the mortgage asset class (text chart). While only 1.8 percent of FX mortgages are impaired, multiple risk factors (e.g., adjustable-rate mortgage (ARM), extremely high loan-to-values (LTVs), long tenors, subsidized mortgages, low PLN portfolio seasoning, and consumer indebtedness) create a negative portfolio outlook amplified by potential effects of changes in the exchange rate, falling asset prices and economic slowdown. While the proportion of impaired FX mortgages to zloty mortgages in the housing loan portfolio has been

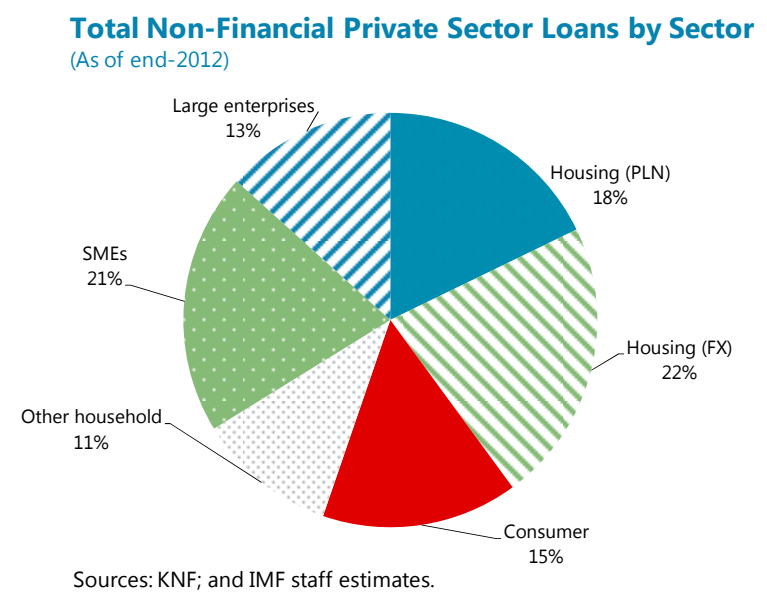
decreasing, the level of impaired FX mortgages continues to increase. Impaired FX mortgages represents four percent of the overall impaired loan portfolio as of year-end 2012.

4. LTV ratios remain quite high for one third of the housing portfolio. The majority of loans with LTVs over 100 percent are FX loans and in fact, 25 percent of the FX housing portfolio has LTVs over 130 percent (text chart). These high ratios are mainly attributable to flexible underwriting standards in the past; the zloty depreciation and falling real estate prices which have yet to stabilize. While the average LTV for newly originated loans is about

\footnotetext{
${ }^{10}$ Aggregate credit growth in these sectors since 2009 has been 25 percent.
} 
70 percent, some banks reported they are continuing to lend at 100 percent LTV. ${ }^{11}$ The remaining mortgage portfolio is exposed to multiple risks. As the present system of covered bonds is nonfunctional and the market for other long-term instruments issued by banks is shallow, the lenders must fund mortgages with short-term domestic deposits creating significant maturity gaps. The market for long-term bonds is constrained by the absence of a deep domestic investor base, partly due to restrictive regulations governing pension funds investment decisions. Legal, tax, and accounting obstacles impede the development of securitization and wider usage of the covered bonds. Recent regulatory initiatives focus on asset quality (stricter FX and LTV guidance), loan transferability and use of long-term funding. The design of the new mortgage subsidy program has also been improved to reduce the uncertainty of fiscal liabilities. The reserve coverage for impaired housing loans, which is

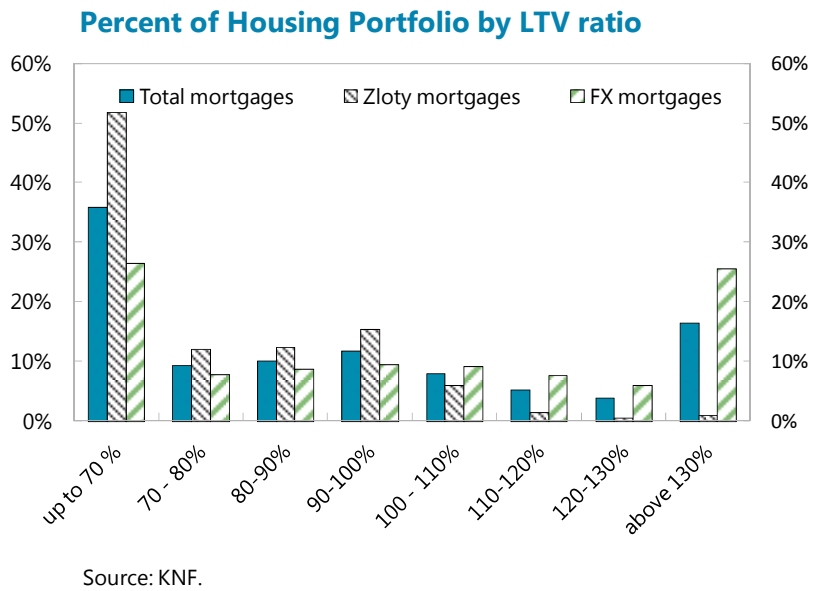
calculated using an incurred loss model under the International Financial Reporting Standards (IFRS) which is backward looking, ${ }^{12}$ is 48 percent which may be low considering the lengthy recovery process and falling residential real estate prices.

\section{The outstanding stock of FX loans remains vulnerable to exchange rate volatility} and has yet to mature. At the aggregate level, the on-balance sheet open foreign currency position is about 5 percent of total commercial bank assets and 45 percent of total bank equity (text chart). Balance sheet currency mismatches, however, require banks to hedge FX risk through FX swaps and cross-currency interest rate swaps. Faced with reduced foreign currency funding from parent banks, a number of foreign subsidiaries are hedging through FX derivatives. Short-term contracts are cheap for hedging but there is a gradual shift

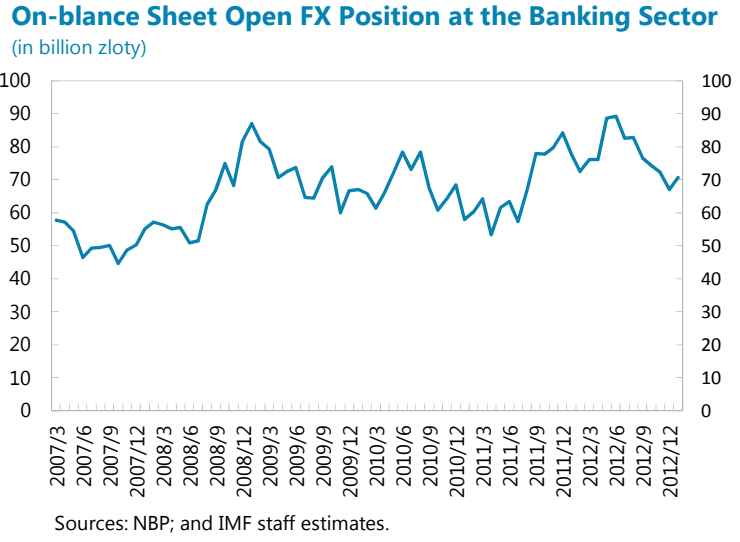
towards using longer-term contracts despite their higher costs; however, the hedging needs

\footnotetext{
${ }^{11}$ Recommendation S requires an $80-90$ percent LTV but this requirement can be waived if certain conditions are met.

12 The International Accounting Standards Board recently issued a proposal for measuring loan loss provisions which incorporates a more forward looking model for recognizing credit losses.
} 
tend to increase as zloty deprecates, likely causing liquidity strains. Hedging needs are declining as the stock of FX mortgages has been decreasing since March 2012 assisted by principal being repaid faster owing to the low level of Swiss franc interest rates and new issuance being close to zero; however, the majority of the total mortgage portfolio is young with a maturity of 10 years or more (text chart). In addition, increased holdings of zloty assets by

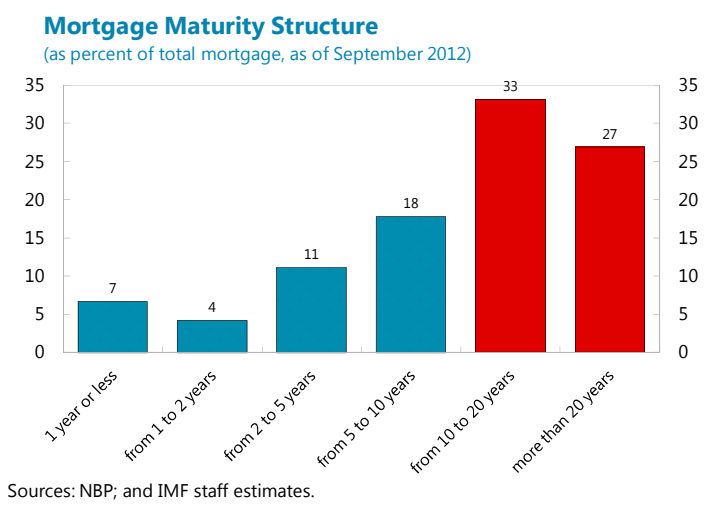
foreign investors - who tend to hedge the zloty risk — support supply of hedging instruments.

\section{KNF's requirements for addressing impaired loans are set forth in several} documents including Recommendation R, Resolution 258/2011, and the Ordinance of the Minister of Finance $2008 .^{13}$ The purpose of Recommendation $\mathrm{R}$ is to set forth principles of good practice in the identification of credit exposures that have become impaired and determination of the valuation allowances. It mainly applies to banks following IFRS. ${ }^{14}$ NonIFRS banks follow the more prescriptive Ordinance of the Minister of Finance of December 2008 which sets forth provisioning guidelines. All banks must adhere to Resolution 258/2011 which requires banks to identify impaired credit exposures; to establish a system for classifying loans based on risk categories and a system of write-offs; and to establish adequate provisions. ${ }^{15}$

\section{Credit UnderWRiting StandaRdS}

\section{While the Banking Law requires banks to assess its clients' repayment ability} and estimate the risk related to the granting of the credit or loan, underwriting standards were quite flexible prior to 2008. For example, many banks' retail consumer lending policies were practically nonexistent as borrowers' income was not always verified and the capacity to repay was not adequately considered. As a result, credit growth

\footnotetext{
${ }^{13} \mathrm{KNF}$ has limited legal powers that have led them to issue nonlegally binding "Recommendations" and "Letters" which are de facto but not de jure regulations and enforced during the supervisory process.

${ }^{14}$ The major banks follow IFRS. A recommendation was made in the 2006 FSAP that would require all banks to follow IFRS; however, the authorities have not implemented this recommendation citing that the regulatory burden for smaller banks would be significant. Smaller banks follow Polish Accounting Standards (PAS).

${ }^{15}$ A BCP ROSC was conducted in 2011 and CP8 on Credit Risk and CP9 on Problem Assets, Provisions, and Reserves were both assigned "compliant;" however, the assessors commented on the need for frequent on-site inspections in order to ensure that banks' provisioning and reserving policies and procedures are properly implemented.
} 


\section{Box 1. An Empirical Analysis on Loan Growth}

In this analysis we attempt to use bank-level data to estimate a panel model of credit growth that includes both bank-specific financial indicators, and key macroeconomic variables to identify supply and demand factors in credit growth. Data are at quarterly frequency and cover the period of 2002Q12012Q3. Bank-level data are from Bloomberg that cover banks' financial condition including asset quality, capital position, liquidity position, and profitability to capture the effect of supply factors. They are represented in lag terms to reduce contemporaneous bias. Key macroeconomic variables include nominal GDP growth to capture demand factor, and change in exchange rates to control for exchange rate valuation effect on loans. Thirteen banks are covered in the analysis, ten of which are subsidiaries of foreign banks. Assets of these banks account for about 60 percent of system-wide assets.

\begin{tabular}{|c|c|c|c|c|c|c|c|}
\hline \multirow{3}{*}{$\begin{array}{l}\text { Dependent varialbe: } \\
\text { gross loan growth (yoy, \%) }\end{array}$} & \multirow{3}{*}{$\begin{array}{c}\begin{array}{c}(1) \\
\text { Baseline }\end{array} \\
\text { FE } \\
\end{array}$} & \multirow{2}{*}{\multicolumn{2}{|c|}{$\begin{array}{l}(2) \\
\text { Alternative }\end{array}$}} & (4) & (5) & (6) & (7) \\
\hline & & & & \multicolumn{4}{|c|}{ Simpler specifications } \\
\hline & & $\mathrm{RE}$ & Pooled & & & & \\
\hline Nominal GDP growth (yoy, \%, 1st lag) & $\begin{array}{r}1.957^{* * *} \\
(0.44)\end{array}$ & $\begin{array}{r}2.516^{\star * *} \\
(0.44)\end{array}$ & $\begin{array}{r}2.516^{* * *} \\
(0.44)\end{array}$ & $\begin{array}{r}2.210^{* * *} \\
(0.44)\end{array}$ & $\begin{array}{r}2.155^{* * *} \\
(0.45)\end{array}$ & $\begin{array}{r}2.368^{* * *} \\
(0.45)\end{array}$ & $\begin{array}{r}2.847^{* * *} \\
(0.45)\end{array}$ \\
\hline Exchange rate change (+ appreciation) & $\begin{array}{r}-0.650^{* * *} \\
(0.15)\end{array}$ & $\begin{array}{r}-0.667^{* \star *} \\
(0.16)\end{array}$ & $\begin{array}{r}-0.667^{* * *} \\
(0.16)\end{array}$ & $\begin{array}{r}-0.645^{\star * *} \\
(0.15)\end{array}$ & $\begin{array}{r}-0.676^{* * *} \\
(0.16)\end{array}$ & $\begin{array}{r}-0.689^{* * *} \\
(0.16)\end{array}$ & $\begin{array}{r}-0.743^{* * *} \\
(0.17)\end{array}$ \\
\hline Non-performing loan ratio $(\%, 1 \mathrm{st}$ lag) & $\begin{array}{r}-3.242^{* * *} \\
(0.43)\end{array}$ & $\begin{array}{r}-3.112^{* \star *} \\
(0.35)\end{array}$ & $\begin{array}{r}-3.112^{* * *} \\
(0.35)\end{array}$ & $\begin{array}{r}-3.574^{\star * *} \\
(0.44)\end{array}$ & $\begin{array}{r}-2.877^{* * *} \\
(0.39)\end{array}$ & $\begin{array}{r}-3.086^{* * *} \\
(0.38)\end{array}$ & $\begin{array}{r}-2.736^{\star * *} \\
(0.39)\end{array}$ \\
\hline Bank size (\% of GDP, 1 st lag) & $\begin{array}{r}-2.686^{\star * *} \\
(1.03)\end{array}$ & $\begin{array}{r}-0.709^{* *} \\
(0.34)\end{array}$ & $\begin{array}{r}-0.709^{* *} \\
(0.34)\end{array}$ & $\begin{array}{r}-3.210^{* * *} \\
(1.05)\end{array}$ & $\begin{array}{r}-4.726^{* * *} \\
(1.00)\end{array}$ & $\begin{array}{r}-4.302^{* * *} \\
(1.00)\end{array}$ & \\
\hline Capital adequacy ratio $(\%, 1$ st lag) & $\begin{array}{r}-1.372^{\star \star *} \\
(0.52)\end{array}$ & $\begin{array}{r}-1.458^{* * *} \\
(0.47)\end{array}$ & $\begin{array}{r}-1.458^{* * *} \\
(0.47)\end{array}$ & $\begin{array}{r}-1.322^{* *} \\
(0.53)\end{array}$ & $\begin{array}{r}-1.208^{* *} \\
(0.54)\end{array}$ & & \\
\hline Net interest margin (\%, 1st lag) & $\begin{array}{r}4.091^{* *} \\
(1.64)\end{array}$ & $\begin{array}{r}2.243^{*} \\
(1.17)\end{array}$ & $\begin{array}{c}2.243^{*} \\
(1.17)\end{array}$ & $\begin{array}{r}3.910^{* *} \\
(1.68)\end{array}$ & & & \\
\hline Dummy (1 if LDR>1, 1st lag) & $\begin{array}{r}-10.54^{\star * *} \\
(2.95)\end{array}$ & $\begin{array}{r}-4.700^{\star *} \\
(2.11)\end{array}$ & $\begin{array}{r}-4.700^{\star *} \\
(2.11)\end{array}$ & & & & \\
\hline Observations & 220 & 220 & 220 & 220 & 228 & 229 & 229 \\
\hline R-squared & 0.511 & & 0.513 & 0.48 & 0.435 & 0.419 & 0.368 \\
\hline Number of bank & 13 & 13 & & 13 & 13 & 13 & 13 \\
\hline
\end{tabular}

Standard errors in parentheses. Data points with missing varibles are excluded in the regression.

${ }^{* * *} p<0.01,{ }^{* *} p<0.05,{ }^{*} p<0.1$. Hausman test rejects random effects.

The estimation results suggest that credit growth is positively associated with economic expansion. Clearly economic expansion stimulates the demand for credit. The appreciation of zloty will deflate the amount of credit through the FX evaluation effect. On the bank specific characteristics, larger banks tend to expand less aggressively than smaller banks. Banks with strong capital positions are more conservative in expanding credit than banks with less strong capital positions. Banks with higher income generating power tend to expand credit more rapidly. Banks with loan to deposit ratio above one expand credit less aggressively. More important, the results demonstrate the banks with higher NPL ratios tend to expand credit slowly, which are significant in all the model specifications. These results support the call for more proactive measures for banks to deal with problem assets to reduce NPL ratios and hence to relieve space for lending. 
and the level of impaired loans in the retail consumer sectors increased significantly. Banks started to tighten their underwriting practices after the crisis in 2008 and to specifically address the risk in the retail consumer sector; KNF issued very prescriptive requirements to the banks in 2010. Recommendation T, as it is known, was designed to improve the standards for assessing creditworthiness of retail clients. It restricted DTI levels to 50 percent to 65 percent; required potential borrowers to produce income certificates and detailed specific supervisory expectations (Table 1).

\section{Table 1. Poland: Comparison of Selected Features of Regulatory Recommendations for Mortgage and Retail Loans}

\begin{tabular}{|c|c|c|c|c|}
\hline & \multicolumn{2}{|c|}{ Mortgages } & \multicolumn{2}{|c|}{$\begin{array}{l}\text { Retail Loans } \\
\end{array}$} \\
\hline & Existing Rec. S & Proposed Rec. S & Previous Rec. T & Revised Rec. T \\
\hline DTI & $\begin{array}{l}42 \text { percent for } F X \\
\text { mortgage loans }\end{array}$ & $\begin{array}{l}\text { Thresholds lifted but } \\
\text { caution to DTIs } \\
\text { exceeding } 40-50 \\
\text { percent }\end{array}$ & $50-65$ percent & Thresholds lifted \\
\hline LTV & $\begin{array}{l}80-90 \text { percent but } \\
\text { waived if certain } \\
\text { conditions are met }\end{array}$ & $\begin{array}{l}80 \text { percent or } 90 \\
\text { percent with credit } \\
\text { insurance }\end{array}$ & N/A & N/A \\
\hline $\begin{array}{l}\text { Income } \\
\text { procedures }\end{array}$ & $\begin{array}{l}\text { Verify income on all } \\
\text { loans }\end{array}$ & $\begin{array}{l}\text { Link currency of the } \\
\text { borrower's income } \\
\text { mortgage currency }\end{array}$ & $\begin{array}{l}\text { Evaluate } \\
\text { sources of } \\
\text { income closely } \\
\text { and require } \\
\text { income } \\
\text { certification }\end{array}$ & $\begin{array}{l}\text { Simplified } \\
\text { procedures for } \\
\text { customers } \\
\text { meeting certain } \\
\text { criteria; income } \\
\text { statements or } \\
\text { account history } \\
\text { used instead of } \\
\text { income } \\
\text { certificates; }\end{array}$ \\
\hline $\begin{array}{l}\text { Board } \\
\text { Oversight }\end{array}$ & & & & $\begin{array}{l}\text { Bank must report } \\
\text { exceptions to } \\
\text { adopted rules to } \\
\text { the Board }\end{array}$ \\
\hline
\end{tabular}

Source: Polish authorities.

8. To address FX mortgage lending risk, KNF started taking a number of measures in 2006. The first set included such measures as conducting stress tests with the assumption of 30 percent zloty depreciation and stronger requirements for assessing creditworthiness in case of borrowers applying for FX mortgage loans. The second and third sets of measures were more robust and came into force in April 2009 and in the second half of 2011. The 
measures contained very prescriptive rules including restricting LTV ratios to 80 percent to 90 percent and establishing DTIs thresholds for FX mortgage borrowers at 42 percent. ${ }^{16}$

\section{Banks appropriately responded to both of these measures and tightened lending} policies. Impaired loans started to level off in 2010 and asset quality improved. However, Recommendation $\mathrm{T}$ also resulted in regulatory arbitrage in the retail sector. Potential borrowers who had been rejected by the banks started turning to nonbank financial institutions to obtain credit. ${ }^{17}$

\section{To address these inefficiencies in the retail sector, authorities have recently} revised Recommendation $\mathbf{T} .{ }^{18}$ While the new requirements will tighten standards in some areas, other standards will be made more flexible. For example, regulatory thresholds will be lifted for DTIs and income verification procedures will be dependent on loan size and duration of customer relationship with the bank. One of the motivations behind these changes is mainly to prevent consumers from taking their business to foreign nonbank finance companies offering easier credit.

\section{Authorities are also contemplating changes in Recommendation $\mathbf{S}$ to strengthen} the mortgage sector. The draft Recommendation S will introduce explicit LTV limits for all mortgages and the requirement to match the currency of the borrower's income with the currency of the mortgage. ${ }^{19}$ While this is a positive move forward, draft Recommendation S would benefit from fine tuning mainly related to DTIs and use of credit risk insurance as the current proposal would also loosen requirements for DTIs as noted above. ${ }^{20}$

\section{To ensure that banks' underwriting practices do not drift towards those observed pre-2008, supervisors will need to intensely supervise the banks' credit risk management practices closely. Banks will be responsible for establishing their own DTI}

\footnotetext{
${ }^{16}$ Banks that are able to show evidence of reliable recovery rates may have more flexibility regarding LTV requirements and be able to establish their own internal limits.

${ }^{17}$ While the scale of this phenomenon is difficult to assess quantitatively, authorities estimated that consumer lending comprised about 0.5 percent of GDP.

${ }^{18}$ The authorities' overall intent of the revisions was to deploy the DTI in addressing structural issues (i.e., tight underwriting standards) and increase bank sector credit overall; however, one of the specific underlying objectives was to re-engage customers who had exited the formal banking system.

${ }^{19}$ Contemplated changes to Recommendation S also include requiring banks to pay special attention to loans that would bring the DTI for a given client above 40 percent or 50 percent (depending on income).

${ }^{20}$ See discussion of covered bonds in the Aide Memoire and FSSA for additional details on the recommendation related to Recommendation S. Recommendations include tightening DTI to 40 percent and imposing stringent conditions applied to such insurance vis-à-vis related party transactions, pricing, and other regulatory treatment (e.g., capital adequacy ratio or provisioning rules applicable to such insurance).
} 
thresholds for retail loans. As a result, there is a potential risk that some banks may loosen internal lending policies and adopt similar practices prevalent prior to 2008. Ensuring high asset quality from the point of loan origination will reduce the risk of a loan becoming impaired in the future. Establishing a standard methodology for calculating DTI would be very useful so banks' are not tempted to manipulate the calculation and lending policies and practices could be evaluated on a consistent basis by supervisors. ${ }^{21}$

\section{The establishment of a credit bureau has also improved the bank's ability to} assess borrower's creditworthiness. The Biuro Informacji Kredytowej S.A. (Credit Information Bureau) (BIK) is based in Warsaw and more than 600 banks and credit unions are reporting positive and negative information on its borrowers. However, nonbank financial institutions do not report to the bureau although lending by this sector is increasing. Establishing mechanisms to encourage these companies to report would assist banks in their credit underwriting decisions.

\section{Provisioning for ImPaired Loans}

\section{Banks have established their own loan rating system and calculate their} provisions for impaired loans based on the accounting framework they have implemented. The majority of banks has implemented IFRS and as such, applies an incurred loss approach in determining provisions for impaired loans. Banks that have not adopted IFRS follow Polish Accounting Standards (PAS) and as such, calculate their provisions based on an asset classification system commonly used in many countries. Under this approach, loans are classified as satisfactory, special mention, substandard, doubtful, or loss. Provisions are determined according to these categories of risk. These categories are generally based on the number of days past due and for certain loans on the economic condition of the debtor (Table 2). The supervisory requirements for identifying impaired loans and calculating impaired losses and provisions for banks applying IFRS are set forth in KNF's Recommendation R and the requirements for banks applying PAS are set forth in a prescriptive Ordinance issued by the Minister of Finance. ${ }^{22}$ The KNF has the power to request additional provisions and has used this power in the past.

\footnotetext{
${ }^{21}$ For example, is the DTI based on gross or net income? What constitutes "financial liabilities" when determining the customer's expenses?

${ }^{22}$ Recommendation R was issued in 2006 and updated in 2011, and the Ordinance was issued in 2008.
} 
Table 2. Poland: Provisioning for Accounting and Tax Purposes

\begin{tabular}{cccc}
\hline $\begin{array}{c}\text { Category or Risk } \\
\text { Rating }\end{array}$ & $\begin{array}{c}\text { Provisioning } \\
\text { under IFRS }\end{array}$ & $\begin{array}{c}\text { Provisioning } \\
\text { under PAS }\end{array}$ & $\begin{array}{c}\text { Tax Deductibility for } \\
\text { Tax Purposes }\end{array}$ \\
\hline Impaired & $\begin{array}{c}\text { Incurred loss } \\
\text { model }\end{array}$ & N/A & N/A ${ }^{23}$ \\
Normal & N/A & $0-1.5 \%{ }^{24}$ & $0 \%$ \\
Special Mention & N/A & $1.5 \%$ & $0 \%$ \\
Substandard & N/A & $20 \%$ & $0 \%$ \\
Doubtful & N/A & $50 \%$ & $\begin{array}{c}25 \% \text { one year over due or } \\
\text { become doubtful (50\% for } \\
\text { restructured corporate) }\end{array}$ \\
Loss & N/A & $100 \%$ & $\begin{array}{r}100 \% \text { after legal } \\
\text { documents proving } \\
\text { recoverability is probable }\end{array}$ \\
\hline
\end{tabular}

Source: Polish authorities.

15. While the overall reserve coverage is $\mathbf{5 4}$ percent, the ratio varies for each sector and ranges between 36 percent and 77 percent as of December 31, 2012 (text chart). It is difficult to gauge the adequacy of the level of provisioning for each sector since the models used by financial institutions to calculate their reserves will vary and assumptions will vary given the composition of different loan portfolios, loan concentrations, Probability of Defaults (PDs), Loss Given defaults (LGDs), cure rates, expectancies, and recovery rates. Nevertheless, it appears low for the SME sector (36 percent) and housing sector (48 percent), especially

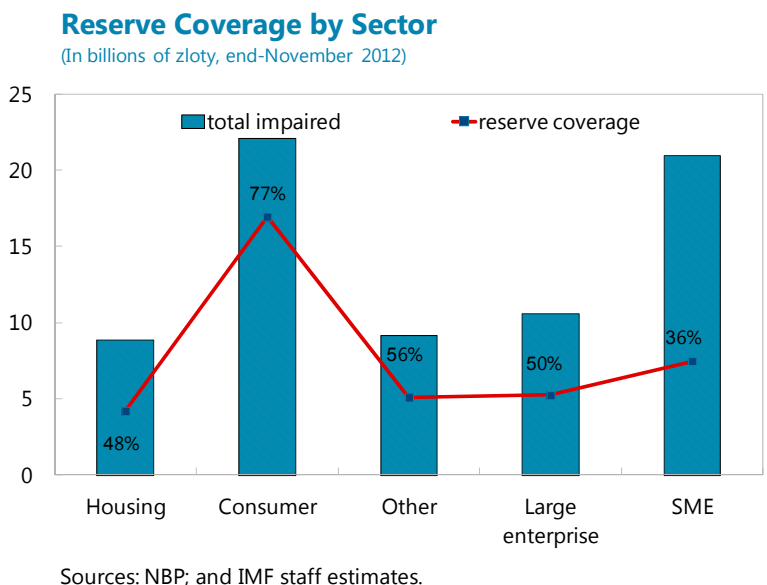
given the long recovery process and falling asset prices, raising the potential loss given default. ${ }^{25}$ Given the decline in the macroeconomic conditions - slower GDP growth and

\footnotetext{
${ }^{23}$ Tax deductibility is based on the categorization of loans under PAS. Banks applying IFRS can deduct the equivalent of charges that would be deducted under PAS.

${ }^{24}$ Provision of 1.5 percent applies only to retail loans.
} 
rising rate of unemployment, impaired loans are expected to increase. As such, supervisors should ensure adequate off-site and on-site monitoring of impaired loans and the adequacy of the provisions.

16. Supervisors are aware of the flexibility in applying the accounting standards and intend to conduct a thematic review in 2013 of impaired loans which will focus on the incurred loss model as prescribed by IFRS. The scope of the review will include the 13 largest banks. The standards allows a high degree of flexibility in determining the assumptions for the model and the supervisors have not issued any guidance that would standardize the interpretations used in applying the accounting principles beyond

Recommendation R. For example, banks may have different interpretations of the accounting standards and as such there could be a lack of consistency to the risk inputs with some banks making less conservative assumptions than others resulting in a level of provisions that may not reflect the true risk of the exposure. Supervisors need to promote strong provisioning practices and in this case, standardize accounting practices. ${ }^{26}$ In some countries, supervisors have issued their own regulations or guidelines which set forth specific approaches for calculating provisions that may yield different (and higher) results than IFRS. Examples include Spain, Romania, and Bulgaria and many countries in Latin America. The authorities should use the findings of the thematic reviews as a basis for modifying Recommendation $\mathrm{R}$ or in developing new guidance.

\section{The tax laws provide incentives for banks to under-provision. All banks must} maintain a loan classification system to calculate loan provisions for tax purposes. For tax purposes, provisions for doubtful debts are generally deductible under certain conditions up to the amount of 25 percent of the debt (50 percent for restructured corporate loans) and provisions for the remaining losses are fully deductible when the loss is legally confirmed by the court or proven probable according to the tax law, for example by death, legal insolvency, liquidation, or restructuring of the debt. While banks appropriately charge the provision against income for financial reporting purposes, they are unable to claim the charge as a deduction for tax purposes. Therefore, their income will be higher for tax purposes. A deferred tax asset (DTA) will be recognized on the financial statements for these negative temporary timing differences since they will recognize a future benefit when they are

\footnotetext{
${ }^{25}$ The European Banking Coordination "Vienna” Initiative's Report from the Working Group on NPLs issued in March 2012, which focuses on Central, Eastern and Southeastern Europe countries (CESEE), indicates that CESEE countries have relatively high provisioning levels at two thirds of NPLs which is the level that is typically considered prudent. While this report focuses on CESEE countries, it is implying that a coverage ratio of 66 percent can be considered prudent for other countries.

${ }^{26}$ Not all banks have been approved for the advanced approach for calculating credit risk under Basel II; however, the Basel principles require banks to deduct from Tier one capital the difference between the expected losses calculated for capital purposes and the losses calculated for accounting purposes if the expected losses are higher. Some countries using the standard approach have also applied this prudential filter.
} 
allowed to deduct the provisions from income for tax purposes (to the extent that it is probable that taxable profit will be available against which the deductible temporary difference can be utilized). ${ }^{27}$ Under Basel III, DTAs that rely on future profitability of the bank are deducted from Common Equity Tier 1 since these types of assets do not offer adequate protection against losses. ${ }^{28}$

18. The increased tax deductibility of loan losses would provide a strong incentive to set aside adequate loan loss provisions. While it appears that the major banks provisioning practices are not significantly affected by the tax law in Poland, a friendlier tax law would certainly provide more incentives. In addition, despite the difference in tax and accounting treatment of provisions, supervisors could also establish rules that would require impaired loans to be provisioned for 100 percent after a certain period of time (e.g., 100 percent provisioning is required after 2 years for unsecured loans or 3 years for secured loans). ${ }^{29}$

\section{Writing OfF BAD DebTS}

19. Various laws pose disincentives for banks to write off their bad debts. Under the tax law, banks are not allowed to fully deduct debts that have been written off unless certain legal conditions have been met. These include:

- Decision of noncollectability that is issued by the authorized enforcement body;

- $\quad$ Bankruptcy request that has been dismissed by the courts because the assets are not sufficient to cover the costs of the proceedings; and

- $\quad$ The taxpayer files a statement that the expected costs of enforcement proceedings would exceed the amount of the claim.

Electronic courts have made it more efficient for banks or other debt collector to obtain an enforcement, which is one of the instruments, required showing proof of noncollectability. However, while these burdensome court procedures are improving, other issues exist in this on-line system such as high frequency of data errors related to borrowers' debt information.

\footnotetext{
${ }^{27}$ For example, one bank reported tax deferred assets attributable to loan loss provisions is less than one percent of the total assets. About four percent of its provisioning expenses were tax deferred.

${ }^{28}$ The value of a DTA depends on the bank generating future profits so that the associated tax liability may be reduced. If the bank is unable to generate sufficient profits, the benefit would not be realized and the DTA must be written down, thus reducing available capital. Regulators are concerned about banks accumulating large amounts of DTAs which could disappear in bad times when banks' profits evaporate and at exactly the point at when capital is needed.

${ }^{29}$ One Polish public bank indicated during the discussions that that they have adopted such a policy.
} 
20. The tax law and other laws should be made more flexible so that banks are encouraged to write off their loans in a timely manner. Writing off noncollectible loans ${ }^{30}$ in a timely manner is a sensible practice endorsed by supervisors around the globe. The Basel Core Principles also expects supervisors to require banks to periodically review write offs. The "Vienna Initiative" Working Group on NPLs issued a report in 2012 which also supports supervisors encouraging banks to write off their loans. In Poland's case, over 40 percent of the banks' nonfinancial loans past due over one year are consumer cash loans so there is no prospect of recovery (Figure 2). Moreover, some banks are reporting they have loans that are overdue 60 months or more that are sitting on their balance sheets. ${ }^{31}$ The tax law should accommodate this situation and allow for banks to fully deduct from taxable income their nonrecoverable assets without having to obtain court documents. The KNF and the Poland Banking Association should be more aggressive and consult the tax authorities and push for changes in the law.

Figure 2. Poland: Past-due Loans

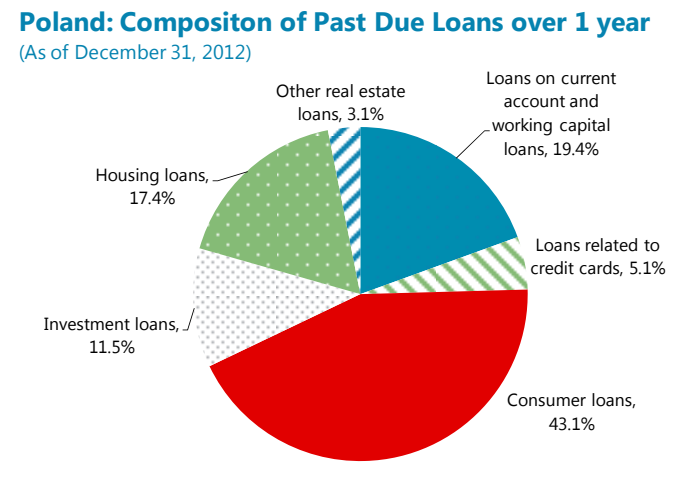

Sources: NBP, and IMF staff estimates.

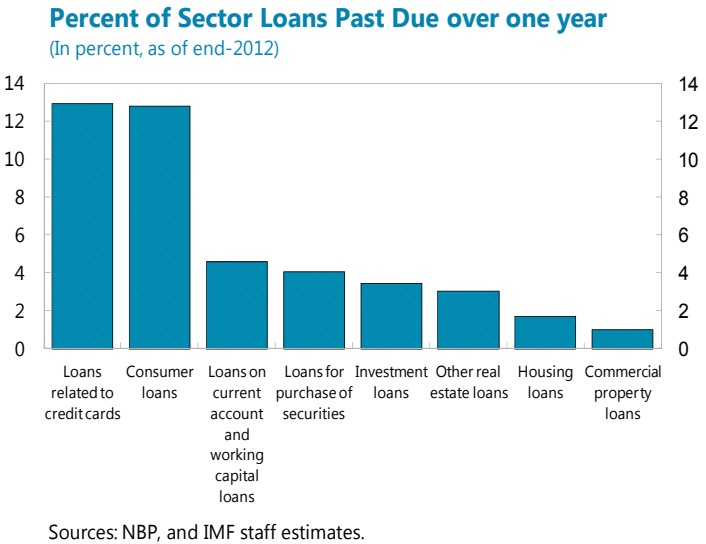

Percent of Sector Loans Past Due over one year

Sources: NBP, and IMF staff estimates.

\section{Many countries' tax laws contain provisions for banks' bad debts that include} specific write off schedules based on the overdue period. For example, in the Czech Republic, a certain percentage of a loan may be "written off" and deducted for tax purposes depending on the overdue period, so, if a loan is overdue by 36 months, 100 percent of the balance may be written off. However, starting January 1, 2015, it will be possible to deduct 50 percent and 100 percent provisions that are 18 or 36 months overdue, respectively,

\footnotetext{
${ }^{30}$ The amount to write off takes into consideration the value of collateral and cost of collection.

${ }^{31}$ For example, in an Annual Report of a public bank, 25 percent of its impaired loans are at least five years past due.
} 
without the need to initiate the collection procedure. Another example is Portugal which allows a tax deduction for impairment losses based on the overdue period which ranges from 25 percent at 6 months to 100 percent at 24 months. While such schedules would assist in providing additional incentives for banks to provision adequately, the creditor should attempt to collect the claim using all reasonable efforts in all cases.

\section{Interest ACCRual Practices}

\section{Major banks follow IFRS and continue to accrue income on the net present} value of the loans. There is no suspension of interest, or nonaccrual, concept in IFRS and supervisors have not issued alternative guidance to this rule that would require banks to stop accruing interest income on loans when it becomes probable that repayment will not occur. In comparison, the accounting treatment under other accounting frameworks, such as Generally Accepted Accounting Principles (GAAP), ${ }^{32}$ has also been silent on the requirement for nonaccrual treatment for delinquent loans at least until recently. Nevertheless, in certain countries, supervisors require banks to place loans on nonaccrual status under certain conditions. ${ }^{33}$ The supervisory guidance is clear and specific and all banks are expected to observe the regulatory requirement, which in turn is observed for accounting purposes.

\section{The Polish law allows banks to accrue a statutory limitation interest amount for} three years which provides further disincentives to writing off loans in a timely manner. ${ }^{34}$ There is strong correlation between the accrued interest and nonperforming loans (text chart). Under Polish law, a debtor is relieved of its obligations after three years of nonpayment if there has been no successful attempt to collect on the debt. However, debt collectors are extremely forceful in Poland and if the debt is turned over to the courts before the three year period has expired, the bailiff has the right to seize the debtor's bank account or payroll. Consumer protection laws are underdeveloped and many debtors are unaware of the three

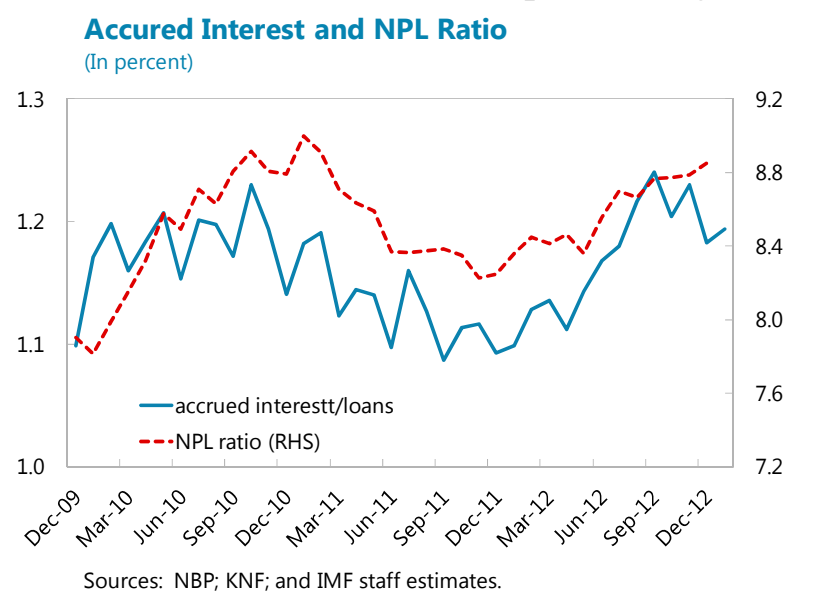

\footnotetext{
${ }^{32}$ Generally Accepted Accounting Principles as issued by the Financial Standards Accounting Board in the United States.

${ }^{33}$ In the United States, the federal bank supervisors require assets to be reported as being in nonaccrual status if the principal or interest has been in default for a period of 90 days or more unless the asset is both well secured and in the process of collection.

${ }^{34}$ In 2012, the rate was set at 13 percent; however, in practice banks impose higher interest rates on past due loans.
} 
year statute of limitations.

24. Ensuring that expected income is properly measured and disclosed is an essential element of an institution's risk identification process and overall loan portfolio management. In Poland's case, most banks follow IFRS, and as such, will accrue interest on impaired loans. However, they will also measure impairment losses by calculating the net present value of estimated future cash flows which would include estimated future interest income. The difference between the current balance of the loan and the discounted cash flows is the amount of provisions or impairment loss that is charged to income. As a result, in theory, the estimated future interest revenue would be offset by these provisions charged to income. However, on an operational level, applying the IFRS credit loss impairment principles are significantly more challenging and complex than applying a simple nonaccrual principle and as a result, there is more margin for error. ${ }^{35}$ Accordingly, and for regulatory purposes, to strengthen loan portfolio management, the Polish authorities should consider issuing guidance that would require banks to cease accrual of interest if the collection of substantially all of the outstanding principle or interest of a borrower's debt is not probable. This regulatory requirement could also be observed for accounting purposes.

\section{ApProaches TAKen to Address BAd DebTS}

\section{A. Restructuring Loans-Retail and Corporate}

\section{Restructuring is the first step banks take to deal with overdue loans. For}

consumer and small SME overdue loans, loan contracts are modified to allow for longer maturity, balloon payment, lower installment for a certain period of time, or reduce interest on principal. Banks reported that they often monitor borrowers' income and cost of living when negotiating with borrowers. To provide incentives for restructuring, banks sometimes waive restructuring fees for the first-time restructuring.

\section{Banks reported that they are willing to engage in voluntary out-of-court} restructuring with corporate borrowers and are making effort in this area. The decision on whether to restructure or to go through court-based debt collection process is usually determined by restructuring experts in a bank. The available resources and expertise needed to engage in corporate debt restructuring is still limited in Poland. Banks reported that they would allow more time for companies with good business prospects to repay. Banks are

\footnotetext{
${ }^{35}$ The nonaccrual principle has been embraced in the U.S. by the Financial Accounting Standards Board and in its exposure draft on impairment has included an explicit nonaccrual principle which states "An entity shall cease its accrual of interest income when it is not probable that the entity will receive substantially all of the principal or substantially all of the interest." This approach considers the recognition of interest revenue and the recognition of expected credit losses separately. The IASB has not adopted a similar approach in its exposure draft on impairment and intends to maintain its current approach which will represent the economic return in a manner that is achieved through the measurement of the gross carrying amount of and expected credit losses at a present value.
} 
strengthening their corporate restructuring departments by increasing their size and introducing new procedures and realigning processes and decision making functions but their sizes still remain a fraction of the size of the retail collection departments.

27. However, it is reported that when there are multiple creditors, creditors' right may not have enough protection. Banks are willing to engage in negotiation with other creditors. Nevertheless, the protection on creditors is limited, as an out-of-court deal may be judged as invalid, if proved that this deal brings grievance to other creditors within two years after the deal is done. To protect the creditors, an out-out-court code of conduct needs to be adopted soon by the financial sector in Poland.

28. There are tax disincentives for out-of-court restructuring. A loss arising from outof-court restructuring is not tax deductible for a creditor. A legal process of collection is needed for the loss to be qualified as tax-deductible. The forgiveness of a debt is treated as income for the debtor. This may be less of an issue for insolvent companies as they may not generate profits even with the forgiveness as income. However, to reduce the disincentive, the creditor should be able to treat the forgiveness as tax deductible costs, especially if the receivables have been reported as taxable revenue. In addition, for retail borrowers subject to personal income tax, this is a major disincentive.

29. Hence, one way to reduce the disincentive is to exempt debt relief from personal income tax while limiting the possibility of tax evasion. A few EU member countries (Belgium, France, and Italy) allow for out-of-court restructuring bad debt with provisions against tax evasion. In these countries, the protection against tax evasion is found in the general anti-avoidance concepts, and given that they are not necessarily legal provision, they are usually vague and require judicial interpretation. As a result, the uncertainty in this area is conceived to be a higher burden for the taxpayer to prove that no avoidance is in play. In Italy and Belgium, there is a tax exemption of debt forgiveness, if the debtor is an individual (nonbusiness). In Italy the exemption is only available for out-of-court restructuring if the taxpayer can proof insolvency or another financial distress that required restructuring. The Italian approach seems at least to be the best developed so far; nevertheless, a legal provision, rather than general anti-avoidance concepts, would be preferred.

30. In summary, ensuring adequate creditor protections and eliminating tax disincentive are important as they will provide incentives for out of court restructurings and the authorities are encouraged to move forward in a timely manner.

\section{B. Restructured Loans-Regulatory Aspects}

\section{Regulatory reporting practices are uneven and the data collected by KNF} indicates that less than two percent of the total loans have been restructured. Of those restructured, over 70 percent are impaired. The reserve coverage for restructured loans is only 55 percent. Banks are currently reporting only total loan balances based on the original due date and actual due date of the loan and total provision amounts so, it is difficult to 
analyze the asset quality in this part of the portfolio. Banks have different definitions of "restructured" loans and IFRS does not provide sufficient guidance ${ }^{36}$. The authorities should tighten the definition of a restructured loan in line with the Basel Committee on Banking Supervision's guidance (BCBS) ${ }^{37}$

\section{To enhance the supervisors' monitoring of banks' restructuring practices, KNF} should consider collecting more detailed data on the restructured loans. Restructuring practices will vary by bank and it is important for banks to adhere to internal policies regarding these activities. Recommendation $\mathrm{R}$ contains some guidance on restructured loans but this mainly repeats IFRS. Data could include number of times the loan has been restructured, losses, performance, re-aging, amount modified year to date, charge offs, and recoveries. KNF needs to be able to obtain a clear picture of this component of the loan portfolio and ensure that adequate provisions are being made and classification upgrades are proper. Additional guidance may need to be issued to ensure proper prudential treatment of these assets. On-site inspections focused on this part of the loan portfolio would also provide an opportunity to gain further insights into this element of the loan cycle.

33. Transparency could be enhanced via Pillar III disclosures. Under Basel II, banks are required to disclose credit risk management practices. It would be useful if banks disclosed their restructuring practices to facilitate market discipline and increase market participants' understanding of a bank's activities and the controls it has in place to manage its exposures.

\section{Debt Collection-Retail and Corporate}

\section{Banks have specific debt collection procedures for different types of loans. It is} typical for banks to collect sizable loans in-house, while outsource loan collection efforts for small loans with a fee structure based on the success rate and loan amount. For example, banks may outsource collection efforts for loans below a threshold or outsource different pieces of portfolios, such as cash loans, and manage the rest in-house.

\section{Retail and small and medium enterprise loans}

\section{There is a standard procedure established by banks to collect retail and small} SME loans which can be quite lengthy. After the termination of the loan contract, the bank

\footnotetext{
${ }^{36}$ The definition of a restructured loan is contained in Recommendation $\mathrm{R}$ which indicates that a restructuring is a "renegotiation or modification of terms of a loan agreement, receivable or held-to-maturity investment due to financial difficulties of the debtor or issuer."

${ }^{37}$ According to the BCBS's 1999 Loan Accounting Paper, a loan is "a restructured troubled loan when the lender, for economic or legal reasons related to the borrower's financial difficulties, grants a concession to the borrower that it would not otherwise consider." See http://www.bis.org/publ/bcbs55.htm for reference.
} 
sends the contract to a standard or electronic court for collections. Once the creditor obtains the title associated with the contract (after a few months), it will send it to bailiff to collect. For secured loans (e.g., mortgage loans), the title must be sent to the local bailiff where the collateral is located. There is no such restriction on cash loans. In the next step, for mortgage loans, bailiffs will evict the inhabitants and hold auctions to sell the property. This is a legal and formal procedure, whereby only two auctions may be conducted. Price reductions are limited, and if the second auction turns out to be unsuccessful, the creditor sells the contracts to debt collectors, or keeps the collateral and records the asset on the balance sheet as other real estate owned. According to one bank interviewed, the entire process is approximately one year for cash loans, about 2 and 2.5 years for mortgage loans, and several years for SME loans with collateral.

36. Banks reported a few impediments in the process of collecting mortgage loans.

First, the choice of bailiffs for mortgage collection is restricted by the location of the collateral. As a result, the quality of bailiffs may be an issue, or bailiffs may have local monopoly power, which would reduce the efficiency of the process. Second, the process of evicting inhabitants is long due to legal and social constraints, as e.g., evictions are forbidden between November 1 and March 31, unless the evicted person can be moved to other premises. Third, the price limitations placed on the property during the second auction limits the success rate, ${ }^{38}$ especially in the current environment of falling housing prices. The launch of electronic court has been acknowledged, as it speeds up the process. However, there is a need to improve the mechanism to cross-check the information submitted to reduce the error on debtors' information.

\section{Corporate loans}

37. Poland still has a liquidation culture regarding corporate insolvency and the formal process of liquidation is time-consuming and cumbersome. There is stigma associated with bankruptcy. One interviewed bank commented that more than $70-80$ percent of bankruptcies ended up in liquidation, not restructuring. It pointed out that courts have neither the skills nor the interest in restructuring and prefer the liquidation process. It is difficult to provide financing to a company under a restructuring, as the Polish law does not allow for the priority of such financing in the hierarchy of claims. Even if all of the creditors agree that an insolvent debtor can take on additional credit, courts can overrule the agreement. One interviewed bank commented that out-of-court restructuring is more effective than in-court restructuring.

38. Creditors lack an effective voice in the insolvency process. Courts appoint court receivers with full discretion, creating opportunities of favoritism in the appointment process.

\footnotetext{
${ }^{38}$ During the second auction, housing prices cannot be reduced by more than one third.
} 
Creditors have no venue to voice their concerns about the quality of court receivers. The rights of the creditors' council, an advisory body which in theory supervises the court supervisor and court receivers, are very limited. The courts decide which creditors are allowed to sit in the council, and those proposed to set up the council may not be chosen.

39. There is a lack of a sufficient supervisory mechanism. There is no insolvency regulator to take responsible for the oversight of insolvency case. While a judgecommissioner is appointed from the same court, there are insufficient checks and balances and the courts appointed court supervisor is very likely to be the court receiver.

40. In summary, there is a pressing need to improve the insolvency framework with more emphasis on restructuring, increasing creditor's voice, and improving supervision mechanism are crucial in increasing the value and reducing the cost of collectable loans (Box 2). ${ }^{39}$

\section{Market for Impaired Loans}

41. The market for impaired consumer loans has expanded rapidly. A secondary market for impaired consumer loans started in 2004, and markets have grown strongly since 2011, as banks enhanced efforts to dispose consumer impaired loans. Some banks are able to conduct regular auctions to sell impaired consumer loans.

42. Debt collection business is expanding rapidly, but from a low base. The business is profitable with net internal rates of return of about 20 percent to 30 percent. Debt collection agencies have various funding channels - parent funding, money market, equity market, and bond markets. Banks and telephone companies have started to engage in longterm cooperation with debt collection agencies. Collection agencies often set up securitization funds to buy impaired loans. It is easy and attractive to set up a securitization fund (200,000 to 300,000 zloty equity) and some securitization funds are established in offshore centers such as Luxemburg. The fund is exempt from corporate income tax on the income generated from debt collection services. If it can be proved that the fund has other business than debt collection, some exemption from VAT tax is also allowed. In addition, the profit payments to investors are also exempt from withholding tax.

43. The market for mortgage loans is incipient, with few transactions. Debt collection agencies expect this business to develop, as banks will take more efforts to sell impaired loans given the expected deterioration of mortgage portfolio. The fact that bank enforcement titles are nontransferrable may reduce the attractiveness for the demand for impaired

\footnotetext{
${ }^{39}$ The World Bank prepared a ROSC on Poland's Insolvency and Creditor Rights in 2008 and a more recent report "Poland: Towards a Stronger Insolvency Framework" in 2012 which contains numerous recommendations for the authorities to consider. (www.bcc.org.pl/.../Poland_Draft_Final_Report_September_V4.pdf).
} 
mortgage loans. In addition, the same legal and tax impediments to mortgage debt collection are affecting the development of the secondary market.

\section{Box 2. Summary of Polish Bankruptcy Law ${ }^{1}$}

Polish bankruptcy law is codified in the Bankruptcy and Recovery Law of 2003 (in Polish, "Prawo upadlosciowe i naprawcze," and hereafter "Bankruptcy Law"). This law recognizes two types of bankruptcy, and one form of reorganization or recovery proceeding. Despite recent efforts to modernize these statutes, these proceedings are primarily business-oriented, and are deeply-rooted in a creditor-protective tradition. Indeed, consumers have only been eligible to file since 2009, and there are significant restrictions on their use of the bankruptcy system. Overall, the system traditionally has looked to involuntary liquidation and distribution to creditors of assets of defaulting debtors as its goal, and is only very slowly and incrementally moving towards a system that encompasses rescue or rehabilitation.

Polish practices are generally within international norms. The Bankruptcy Law provides for a basic collective proceeding in which the debtor's assets are marshaled and liquidated under the supervision of a court. But there are many aspects that are outside of emerging norms. The legitimate commencement of a case by a single creditor, with a small claim, undermines the notion of bankruptcy as a collective and rehabilitative action, and makes the system more of a large debt collection system. The requirement upon the debtor and its management to file within two weeks of insolvency is not practical, especially given the lack of specificity as to the valuation of assets.

The restriction on consumer filing to only those cases in which there are "extraordinary circumstances beyond [the consumer's] control" is both vague and limiting. The lack of special provisions for prepackaged plans, priority financing during the administrative phase, the exclusion of secured creditor in rem claims contributes to a lack of a fully effective rehabilitation scheme.

Finally, the time limits set forth in the Bankruptcy Law appear to be unduly fast; recovery proceedings, for example, must be dismissed if creditors do not approve a composition within four months, which generally is too short a time to notify all creditors, negotiate a plan, and obtain a favorable vote.

1. Cited from The Assessment of Polish Bankruptcy Law prepared by Mr. Bruce A. Markell (legal expert) and staff of the IMF Legal Department. 